\title{
An Understanding into the Dynamics Faced by Females as they Transition from the Corporate Sector into the Abyss of Entrepreneurship
}

\author{
Sooraya Ebrahim and Shamila Singh
}

Department of Economic and Management Sciences, Mancosa, Johannesburg, South Africa Department of Economic and Management Sciences, Mancosa, Johannesburg, South Africa

\begin{abstract}
Female progressing into executive roles and senior leadership position experience various challenges in the corporate sector. In order to overcome these impediments and barriers many females transition into the world of entrepreneurship. Females expect that the entrepreneurship podium will empower, enhance and uplift their female status and opportunities relative to their male counterparts. Females equally experience a different manifestation of challenges which is similar to the challenges in the corporate sector which is indicative that gender discrimination is pervasive. The extant literature supports the notion that females currently only form $28 \%$ of top decision-making roles in South African businesses and board representation encompasses only $19 \%$ of the female gender. These statistics demonstrate that female progression is stifled by challenges and lag behind their male counterparts. The aim of the research was to assess and understand the dynamics that women face in their senior executive role in the corporate sector as well as when pursuing a career in entrepreneurship. A qualitative research method was utilised and 14 semi-structured interviews was conducted. This approach provided an in depth analysis and understanding of the challenges that female encounter in the corporate sector as well as in the female entrepreneurship environment. The results confirmed a number of factors that impede the progression of females in the corporate and entrepreneurship, namely, male domination, stereotyping, personal barriers, networking, social and cultural beliefs and indoctrination, coaching and mentoring, work-life balance, "pull me down syndrome". In addition, the study also revealed that females create their own selflimiting constraints due to excessive responsibilities, added pressures, motherhood and plainly they prefer not progressing due to their comfort zones and intimidation by males and females alike. In terms of recommendations it was found that programmes, workshops and support structures need to be implemented in order to facilitate female entrepreneurial success and assist females attempting to climb the corporate ladder. Initiatives are hurled at successful, prominent females to become role models and support the sisterhood of female business female advancement and progression in the business and employment sectors. Further research recommends that the sample size of females be increased and to categorise them in terms of race, ethnicity, culture and different hierarchical levels of employment to gain a clearer lens which to view these hindrances that still persist currently. Additionally, the geographical location of these females might provide interesting results in this regard. Furthermore, we can break it down into different industries that females participate in and investigate the impact thereof on female progression.
\end{abstract}

Keywords: Female Empowerment, Discrimination, Difference, Equal opportunity, Intersectionality, Transformation, Affirmative Action, Entrepreneurship.

\section{INTRODUCTION}

Although there is a myriad of legislative frameworks to contribute and accelerate the development and transformation of females the actual progression is still slow. Moreover, especially in South Africa over the past twenty years, much of the agenda of the extant literature was preoccupied with the development of females for leadership roles. Although there had been a predisposition towards equality practices in work environments, females still remain marginalised. In particular, the extant literature makes reference to varied limitations that impede the upward mobility of women in organisations, operating as entrepreneurs, assuming senior leadership positions and board leadership positions. According to the Employment Equity Report (2013-2014) the female representation in 
Sooraya Ebrahim \& Shamila Singh "An Understanding into the Dynamics Faced by Females as they Transition from the Corporate Sector into the Abyss of Entrepreneurship"

senior leadership positions over the ten-year period increased steadily by $6.6 \%$ from $14 \%$ in 2003 to $20.6 \%$ in 2013. Despite the shift towards increased representation it is statistically a marginal increase relative to the Economically Active Population category of women. Despite the level of numeric increase in female progression|representation women still continue to experience substantive inequality in meaningfully contributing, subtle forms of discrimination and progressing further. The lack of transformation and subtle forms of discrimination caused females to venture into entrepreneurship.

\section{MAIN BODY}

Women remain vulnerable and marginalised encountering varied subtle forms of discrimination in all spheres of society. The Employment Equity Report (2013-2014) makes reference to the missing women phenomenon (numeric targets) in that female representation being lower than male representation at middle to senior levels. There is less focus and quantification of the other forms discrimination which hampers female progression. Mbabane (2014: 5) makes reference to the "soft aspects" of employment equity (other forms of discrimination). Mbabane (2014: 6) further argued that alongside quantitative measures there must be a focus on the transformation of attitudes, cultures, practices and behaviours. The soft aspects of employment equity impede and constrain transformation efforts. In the extant literature a number of reasons are cited for frustrating the progression of women, in particular, the lack of skills and knowledge, experience, working hard, unequal pay, internalised oppression, stereotypes, discrimination and a shortage of female mentors (Nombela, 2014: 44 and Warnat: 2012: 23).

Frustrated by slow transformation efforts in the corporate sector females became attracted to the burgeoning entrepreneurial opportunities, interventions and empowerment programmes. Weyer(2007: 483) expounded that the fundamental reason females venture into Entrepreneurship was due to the "Glass Ceiling". The GEM's (Global Entrepreneurship Monitor, 2011) which is a primary measure of total early-stage entrepreneurial activity (TEA) revealed that South Africa's entrepreneurial rate remained steady from $(8.9 \%$ in 2010$)$ to $(9.1 \%)$ in 2011 . The GEM statistics show that female involvement in early stage entrepreneurship increased between 2006 and 2011, but by a much smaller percentage relative to male involvement.

The research seeks to understand the impediments and constraints that females experience in the progressing in the formal employment and whether the impediments or constraints are similar or different for women entrepreneurs.

\section{Problem Statement}

As a result of the slow rate of female progression frustrated by a myriad of challenges in the corporate sector (Employment Equity Report, 2013-2014) women are venturing into the abyss of entrepreneurship. The extant literature too demonstrates that females encounter similar and different challenges in the corporate and entrepreneurship realms. Research by Weyer (2007: 483) and Pai and Vaidya (2009:106) argued that the diversification of the senior management and executive tier is constrained by the glass ceiling effect. Although there are opportunities to enter into the Entrepreneurship market, the failure rate amongst female entrepreneurs are high (anonymous). The rate of failure as entrepreneurs is attributed to a number of variables relating to skills, experience and funding. More specifically the impediments to success of female entrepreneurs relate to a lack of access to finance, inability to provide collateral to obtain loans, lack of business experience and training, lack of support systems, lack of acceptance in the community, male prejudice, lack of managerial skills, poor access to information and advice and the lack of entrepreneurial knowledge (Neil and Viljoen, 2001: 37). More research is needed to fully understand the barriers, challenges, obstacles and constraints experienced by women in the employment sector and as entrepreneurs.

\section{Objectives of the study}

- To determine the impediments of female executives progression in the corporate sector

- To determine the reasons for females selecting and pursuing a career in entrepreneurship

- To ascertain/determine the challenges faced by the female entrepreneurs

- To provide recommendations for the progression of female executives within the corporate sector 
Sooraya Ebrahim \& Shamila Singh "An Understanding into the Dynamics Faced by Females as they Transition from the Corporate Sector into the Abyss of Entrepreneurship"

\section{LITERATURE REVIEW}

The literature outlined here below covers the definitions of female empowerment, female entrepreneurship, theories and models of discrimination; challenges faced in female progression within the corporate sector and the entrepreneurship environment and legislation that promotes female empowerment will be discussed.

\section{Theories Related to Empowerment}

Herein below concepts related to female empowerment are defined to understand the factors that constrain female progression. In particular, discrimination, equity, women empowerment and intersectionality was discussed to frame challenges that constrain female progression in the corporate and entrepreneurship environments.

\section{Intersectionality}

Warnat (2012: 19) expounded that intersectionality is a "paradigm that examines the complex interactions between various social categories, history, social spaces, processes, systems, self, and perceptions of positive and negative norms, to identify areas of oppression and privilege in order to eradicate domination". Further, he argues that there are multiple forms and systems of oppression (racism, sexism, classism, etc.) that determines self-identity and the nature of oppression. Whereas, Dhamoon (2011: 234) opined that constituted structures of domination in the form of colonialism, racism, patriarchy, sexism and capitalism frustrates the people taking autonomous decisions and realise their potential.

Warnat (2012:19) extended the definition to include that transformation is about dismantling the systems of domination, eradicating discriminatory practices and creating opportunities for advancement.

\section{The Concept of Entrepreneurship}

This definition primarily focussed on the element of risk-taking and decisions about resource allocation (Oseifuah, 2010: 8). Varied conceptualisations of entrepreneurs are recognise for their passion and are driven by innovation whereby they create new products, processes, and services for the market.

\section{Theories and Models on Intersectionality}

Two theories, intersectionality (Warnat, 2012: 19) and the regimes of inequality (Acker, 2006: 32) provide a framework to understand systems of domination that prevents transformation.

\section{Regimes of Inequality}

Acker's (2006b: 442) framework focused on power relations and covered the interrelated processes that create and maintain a culture of inequality. In addition, the bases of inequality are conceptualised on the theory of intersectionality perspective to investigate how race, gender and class operate as organising principles of work, organisations and professions and produce inequality.

Acker (2006b: 443) defines inequality regimes as "interrelated practices, processes, actions and meanings that result in and maintain gender, race and class inequalities". The system of domination is linked to broader systems of inequality in society, politics, history and culture. Furthermore, Acker (2006b: 444) argued that disparity is systemic in that participants in power own and control the factors of production and outcomes, make decisions about resources, organise the work and determines the reward and recognition systems. This demonstrates that inequality manifest at all levels in the organisation and society in general. Acker (2006b) used the concept of inequality regimes to understand the reproduction of gender, race and class inequality and to identify the barriers to creating inequality. There are six inequality regimes, namely, shape and degree of inequality; the organising processes that produce inequality; visibility of inequalities; legitimacy of inequalities and control and compliance.

\section{Base of Inequality}

Acker (2006b: 448) postulated that the scope and depth of inequalities vary across organisations although gender, race and class systems are in present in all organisations. Furthermore, Acker (2006: 449) that class emanates from having access and control of resources, whereas gender is socially 
Sooraya Ebrahim \& Shamila Singh "An Understanding into the Dynamics Faced by Females as they Transition from the Corporate Sector into the Abyss of Entrepreneurship"

constructed differences, beliefs and identities that reproduce inequality. Another insight is that gender is fully integrated with class in organisations. In addition, employment practices are shaped by gendered and sexualised attitudes and assumptions (Acker 2006b:450).

Females are reluctant to occupy executive positions associated with risks and responsibilities that impinge on family responsibility and is the major contributing factor for the low proportion of female executives in the work place. Additionally, females prioritise motherhood and family responsibility and subsequently dedicate even less amount of time and resources as opposed to their male counterparts. (Bertrand, Goldin, and Katz, 2010: 5). Niederle and Vesterlund indicate that females' erratic commitment relative to their male counterparts result in the loss of confidence and an inferiority complex. The lack of female progression is attributed to the inability to commit rather than the female capability, performance and productivity. Hence this reveals the contrasting behavioural patterns between the two genders. Therefore, impacting the gender gap in regards to increased promotions of females at the lower levels of the hierarchy as opposed to the higher positions as predicted by the models of Fryer and Bjerk. Another challenge that severely impacts on female progression is "Queen Bee Syndrome", which female supervisors have prejudices against women subordinates which adds to is the "gender discrimination" against females in executive positions.

\section{Shape and Degree of Inequality}

Acker (2006b: 447) postulated that the organisational hierarchy steepness and shape depicts the degree of inequality in the organisation. Thus, the shape, pattern and degree of segregation by race and gender are a determination of the inequality that varies considerably between organisations. In addition, the segregation of gender and race in jobs are complex across different levels of the organisation, jobs at the same level and even within jobs (Charles and Grusky 2004: 10). Also Acker (2006b: 447) argued that class and power differences manifests from the hierarchy. The organisational structure is maintained and legitimised through arguments of women's production, emotionality, and sexuality, helping to legitimise the organisational structures and processes created through abstract intellectualised techniques (Acker, 2006: 448).

Acker (2006b: 448) argued that gendering in work organisations and social institutions occurs in at least five interacting processes: the construction of divisions along lines of gender which refers to the division of labour which relates to hierarchy, sex-role stereotyping, rewards, structures, authority and power and other organizational rules which aid sex segregation of work. Furthermore, Acker argued and agreed with previous scholars that gendering of organizations has an effect on the confidence, lowers the level of commitment and minimizes the career aspirations of females and abates the inferiority complex of women.

\section{Organising Processes that Produce Inequality}

Acker (2006b: 451) argues that "the organisational processes and practices that produce gender, race and class inequalities vary by organisation. Six key elements of the organising processes of work relate to recruitment and selection; training; promotion; wage setting and the informal interactions that occur while doing work.

\section{The Visibility of Inequalities}

Acker (2006b: 452) expounds that visibility refers to the degree of awareness of inequalities which may be intentional or unintentional. Invisibility also relates to inaction, denial and avoidance Organisational processes and practices that generate inequality may be invisible, difficult to identify and fleeting. Acker (2006b: 448) argued that by understanding the visibility of inequities and creating awareness of inequalities will result in designing interventions to eradicate inequality.

\section{Legitimacy of Inequalities}

The legitimacy of inequalities varies between organisations. Acker (2006: 550) opined laws and organisational policies outlaw discrimination on the grounds of race, sex, age, religion, sexual orientation and disability. However, the extant literature indicates that "gender and race inequalities are legitimised in practice through rationalisations built around different capabilities and negative stereotyping". Furthermore, Acker (2006: 551) argued equality strategies will be continually undermined if powerful stakeholders are not championing such interventions. Also the legitimacy of inequalities may be reproduced at different levels in the organisations. 
Sooraya Ebrahim \& Shamila Singh "An Understanding into the Dynamics Faced by Females as they Transition from the Corporate Sector into the Abyss of Entrepreneurship"

\section{Inequality Regimes is Control and Compliance}

Acker (2006b: 448) argued that class-based organisation controls, may be obvious or unobtrusive, direct or indirect. She further argued that the perceived legitimacy of the subordination, fear and intimidation or processes of calculated self-interest serve to maintain a conscious compliance with inequality regimes.

\section{Intersectionality}

Davis (2008:68) argued that intersectionality refers to the interaction between gender, race, and other categories of difference in individual lives, social practices, institutional arrangements, and cultural ideologies and the outcomes of these interactions in terms of power.

Davis (2008: 1245) opined that originally the focus was "on marginalised women whose race, class, and gender worked together to create multiple forms of oppression referred to as triple jeopardy. This analysis proposed that multi-layered systems of domination converge to produce inequality. Poor Black women experience three forms of oppression.

\section{Types of Intersectionality}

Warnat (2012: 24) distinguishes between two types of intersectionality, namely structural domination and postmodernism. Warnat (2012: 25) proposed that structural domination focus on examining the structures that prevent people from accessing power like patriarchy, heterosexism, and racism. In addition, these structures interact with one another to create dominating paradigms (Smith, 2006: 38).

Constructivists and postmodernists argue that people are complex and have their own experiences and hence cannot be categorised into homogenous groups (Phoenix, 2006: 187). Based on the intricacies of individuals broad and universal generalisations cannot be made about groups of people based on categorical differences. Furthermore, theorists argue that generality fails to recognise the differences between individuals in the groups (Dhamoon, 2011: 231). Notwithstanding the types of intersectionality there are common themes that cut across the two types of intersectionality.

\section{Hierarchy of Identities}

Warnat (2012: 26) and Dharmoon (2011: 231) postulate that identity has an order (hierarchy) and the individual will identify more with one aspect of identity than another based on the context. This shifting of hierarchies based on the context was confirmed by a study done on hotel workers. Adib \& Guerrier (2003: 429-430) argued that women's identities shifted depending on the context, and the circumstances that they were confronted with at work reflected and highlighted certain aspects of their identities.

Given the hierarchy of identities, Verloo (2006: 223) argued that in an assessment of inequality there must be a recognition that all inequalities are experienced similarly amongst a group with multiple inequalities. Furthermore, Verloo (2006: 224) opined that intersectionality is useful in that it proposes to categorise different aspects of our identity and be cognisant that hierarchies shift based on the context.

\section{Vertical and Horizontal Interactions}

Employment Equity (2014) makes reference to the "previously" or "historically" having access to equal opportunities yet the Employment Equity Reports (2013-2014) show very little progress. From an intersectionality perspective the historical impact on contemporary world must be acknowledged (Hancock, 2007: 74). Dhamoon (2010: 230) and Henkeman (2011: 25) agreed that a horizontal analysis is needed to account for the past, examine the present, and decide where we want to go in the future

A vertical analysis investigates the various socio-political spaces and how these interact with other aspects of the human experience such as employees' identities (Smooth 2011: 437). For instance, one socio-political space, his/her family setting and if there are stress related to money problems, abuse, or physical ailments, this will inevitably interact with that employee's identity thereby effecting the employee's performance in the workplace.

Furthermore, a "vertical analysis" also examines the interconnections between, various socio-political spaces and history (Smooth 2011: 437). In addition, (Smooth 2011: 437) proposed that as many of 
Sooraya Ebrahim \& Shamila Singh "An Understanding into the Dynamics Faced by Females as they Transition from the Corporate Sector into the Abyss of Entrepreneurship"

these spaces should be included: individual spaces, family spaces, community spaces, organisational spaces, regional spaces, provincial spaces, national spaces, and the global space.

\section{Self-Critique}

An important aspect of intersectionality is to critique individual processes. It requires questioning accepted norms and realities, and the acknowledgement of strengths and weaknesses. Henkeman (2011b) and (Smooth 2011: 438) argues that each of us has a "known" and a "unknown" sides. Furthermore, being aware of the blind spots makes it possible to break the negative cycle of blaming others without doing introspection. (Smooth 2011: 437) encourages individuals to challenge their negative tendencies, and to eliminate negative barriers between the different stakeholders. Diversity programmes contribute to some insights while intersectional analysis warrants in-depth reflection to examine how and why employers and employees participate in different systems of domination.

\section{Domination}

Intersectionality has also evolved to focus on the examination of power relations, which is largely lacking in the EEA and diversity approaches. Intersectionalists question how systems of domination interact with peoples' identities to prevent or support disadvantaged people's ability to access power (Davis, 2008). Intersectionalists have proposed for a complete comprehension and understanding of domination and power relations (Dhamoon 2011:234) in order to be able to commence to abolish domination (Hooks, 2000).

According to (Kuh and Whitt 1988; Hatch and Cunliffe 2006) obstacles hinder women progression in business, namely: restrictions placed on women's rights to own or inherit property; travel; or work at night or limit them to work in certain professions; or to even register their own businesses.

\section{Female Entrepreneurship}

Oseifuah (2010: 31) proposed that the definition of entrepreneurship primarily focuses on the element of risk-taking and decisions regarding resource allocation. Others scholars consider entrepreneurship to be a way of thinking creatively, innovatively, and adopting risk-taking, or resilient behaviour (Foss and Klein 2012: 7)

Entrepreneurs are recognised for innovation and the creation of driven by of the creation of new products, processes, and services for the market (Schmitt, 2007: 205) Furthermore, entrepreneurs resuscitate and enrich individuals and society as a whole and operate in varied business sectors, professions and are action driven in different ways. In addition, entrepreneurs strive towards higher achievement, internal locus of control, remain steadfast by maintaining their composure and selfconfidence.

The 2013 Global Entrepreneurship Monitor (GEM) report indicated that in South Africa, 58\% of entrepreneurs were males and $42 \%$ were females. The report revealed that female entrepreneurs are generally more content and exhibit higher scores on well- being and work life balance. In addition, empirical research has found that $80 \%$ of entrepreneurs with mentoring support survive in the long term as opposed to $45 \%$ that do not have mentoring support and guidance. It can be deduced that mentorship programs either formal or informal programs will increase the rate of success of female entrepreneurs and encourage more females to enter the entrepreneurship market. Mentorship programs have a significant part to play in the upliftment and development of female entrepreneurs. (Business Brief, 2014: 39).

\section{Challenges for Female Entrepreneurship}

According to GEM Report (2013-2014) female entrepreneurs experience a myriad of challenges and barriers, namely gender stereotypes and accepted male vs. female behaviour; limited access to financial resources; gender inequality and gender discrimination; culture and diversity; barriers to entry to certain industries; and under-representation of female representation in top tier business. In addition, an array of issues that relate to a lack life (self-esteem, confidence, motivation, selfassertiveness, positivity) and inadequate support services (mentorship programs, support centres to enhance their skills and advise). Another major challenge relates to balancing the gap between work to household chores and the ever demanding business world. Lastly, there is an increasing trend for women to migrate from senior positions to been self-employed as entrepreneurs as an alternate option, 
Sooraya Ebrahim \& Shamila Singh "An Understanding into the Dynamics Faced by Females as they Transition from the Corporate Sector into the Abyss of Entrepreneurship"

due to limitations encountered in the executive posts for females. Although entrepreneurship poses a varied and significant amount of new and similar challenges for female leaders too.

In the extant literature a myriad of factors in general contribute to the failure of entrepreneurs. Some scholars have categorised the factor affecting entrepreneurship into macro-level forces, regulatory frameworks, demographic and personal factors, culture and education.

\section{International Trends in Female Empowerment}

The Female Entrepreneurship Index (FEI) is the world's first diagnostic tool for comprehensively identifying and analysing the conditions that foster high potential female entrepreneurship development. FEI measures the quantity of female entrepreneurs and also identifies a country's strengths and weaknesses in terms of providing favorable conditions that could lead to high potential female entrepreneurship development.

The Female Entrepreneurship Index (FEI) seeks to identify high potential female entrepreneurs and understand the factors that make them successful in innovation, market oriented and export oriented. The FEI system allows benchmarking cross country factors that affect high potential female entrepreneurial development.

The 2015 Female Entrepreneurship Index (FEI) analysed 77 countries with an established theoretical framework to measure entrepreneurial environment ecosystem and individual aspirations, and score nations from 0 to 100. Key findings from the 2015 Female Entrepreneurship Index including the following:

- The United States ranks first in the world again at 82.9, eight points ahead of 2nd-ranked Australia (74.8).

- In 2015, the UK, Denmark, and the Netherlands featured in the top five, displacing Sweden, France and Germany. All six of these European countries have strong support ecosystems and networks for female entrepreneurs and this can cause shifts in the year to year ranking.

- Of the participating countries 47 of 77 nations still score below 50 points require significant changes to reduce barriers for female entrepreneurs.

- The Latin American countries experienced decline over previous years; Colombia, Peru, Venezuela, and Panama all dropped by at least 5 ranks. Chile ranked at 15 in the overall rankings and is much better than the rest of Latin America countries.

In 2015, the top ten countries for female entrepreneurs are:

Table2.1. Global trends in female entrepreneurship (FEI 2014-2015)

\begin{tabular}{|ll|l|}
\hline \multicolumn{2}{l|}{ COUNTRIES } & RATINGS $(\%)$ \\
\hline 1. & United Sates & 82.9 \\
\hline 2. & Australia & 74.8 \\
\hline 3. & United Kingdom & 70.6 \\
\hline 4. & Denmark & 69.7 \\
\hline 5. & Netherlands & 69.3 \\
\hline 6. & France & 68.8 \\
\hline 7. & Iceland & 68.0 \\
\hline 8. & Sweden & 66.7 \\
\hline 9. & Finland & 66.4 \\
\hline 10. & Norway & 66.3 \\
\hline
\end{tabular}

A number of significant trends emerged from the analysis of the participating countries with regards to female entrepreneurship.

- The report reflects that there has been in an overall increase of $7 \%$ of female entrepreneurs that intend to develop their business by $50 \%$ and employ more than 10 employees within 5 years.

- In terms of the level of level of education the report revealed that there had been an increase of $9 \%$ in female entrepreneurs that participate in some form of post-secondary education. Female entrepreneurs have higher levels of education. 
Sooraya Ebrahim \& Shamila Singh "An Understanding into the Dynamics Faced by Females as they Transition from the Corporate Sector into the Abyss of Entrepreneurship"

- In accordance with the measure of female entrepreneurs' innovativeness and participation in the technology sector female businesses the FEI rating depicts a sharp decline by $13 \%$.

- Amongst the countries that had a FEI rating of below 50,61\% of these countries have to improve women's ability to recognize good opportunity recognition in the area in which they live and start businesses.

The FEI comparison recognize that family oriented policies, like greater provision of childcare services, extended maternity leave and family leave to enable female entrepreneurship. Another trend identified by the FEI is that female entrepreneurs start ventures at a later age (35-40) than men because of work-family conflicts (Shelton, 2006: 5).

Furthermore, OECD (2004: 25) propose that educational training can assist females to build confidence in business acumen to identify entrepreneurial opportunities. Another key dimension is that the levels of female entrepreneurship are also influenced by females' freedom to work determined by differences across countries due to traditional family and religious norms (Terjesen and Elam, 2012). The FEI rankings identified varied factors that affect entrepreneurial development which include equal legal rights, access to education, networks, technology, capital, social norms, values, and expectations. Furthermore, the overall macro and market business environments in terms of laws, regulations, and business stability will affect businesses' ability to thrive and grow.

\section{Glass Ceiling}

Yukl (2013: 371) argued that the "Glass Ceiling" is referred to as the favouring of men over women in filling high-level leadership positions. Also the glass ceiling constitutes an invisible barrier for women and minority groups, preventing them from moving up the Corporate ladder" (Carla and Eagly, 2001; Ridgeway, 2001). Traditionally, gender based discrimination was maintained and reinforced through age old beliefs that men are more qualified than women in leadership roles (Ayman and Korabik, 2010). These evolved beliefs culminated in personal traits, characteristics and skills required for effective leadership in organizations (implicit theories) Furthermore assumptions, cultural values and society about inherent differences between men and women (gender stereotypes) create behavioural roles expectations for men and women which are adhered to.

Oakley (2000) argued that these three categories explain the barriers that promote the glass Ceiling philosophy: (1) Corporate practices such as recruitment, retention, and promotion; (2) Behavioural and cultural causes such as stereotyping and preferred leadership style; and (3) structural and cultural explanations rooted in feminist theory.

Other possible reasons for the glass ceiling effect have been suggested by (Schein, 2001; Tharenou, Latimer, \& Conroy, 1994). The explanations include the following factors, namely:

- Lack of opportunity and visibility in types of positions that would facilitate advancement

- Higher standards of performance for women than for men

- Exclusion of women from informal networks that aid advancement

- Lack of encouragement and opportunity for developmental activities

- Lack of opportunity for effective mentoring

- Lack of strong efforts to gain access to leadership positions

- Difficulties created by competing family demands

- Lack of strong action by top management to ensure equal opportunity

- Bias to select and promote individuals who are similar to the (male) managers who make the decisions and

- Intentional efforts by some men to retain control of the most powerful positions for themselves.

The barriers above are not mutually exclusive or exhaustive and maybe combined in order to fully understand the barriers and limitations imposed in the corporate culture for female leaders. According to the extant literature the glass ceiling is reinforced by varied factors (Bell and Nkomo, 2001: 45; 
Sooraya Ebrahim \& Shamila Singh "An Understanding into the Dynamics Faced by Females as they Transition from the Corporate Sector into the Abyss of Entrepreneurship"

Babcock and Laschever, 2003: 30 and Lyness and Heilman, 2006: 15). Bell and Nkomo (2001: 45) that a major impediment to female progression is the limited access to social and informal networks. Another dimension is that females are less likely to negotiate promotions and salary increases compared their male counterparts (Babcock and Laschever, 2003). In another study Lyness and Heilman (2006) argued that females are required to have more skills and competencies than males for the same positions.

Lueptow et al. (2001) and (Wood and Eagly, 2002) proposed that model and theories of biological explanations, socialisation experiences and structural and cultural explanations account for genderrelated behaviour create the glass ceiling ideology. Although there is little support for the biological school of thought relate to genetic differences, different reproductive patterns and psychological differences that influence functionality and progression.

Instead, socialization and structural/cultural explanations for influencing the barriers to female progression have more traction and provide more plausible explanations. In particular, social constructionist theorist argued that biological differences are understood differently across cultures and it is societal expectations that produce and maintain inequality (Wood and Eagly, 2002). Socialisation theorist propose that gender differences is constructed through various developmental processes associated with life stages, such as schooling and work life and are based on individuals socialisation. Structural and cultural models in the form of social structures and systems shape power and status and cause the leadership differences (Bartol et al., 2003: 9) are the cause for leadership differences attributed to gender. Furthermore, the distribution of different social roles between male and females relatively stable patterns of behaviour emerges (Lueptow et al., 2001).

\section{RESEARCH METHODOLOGY}

The phenomenological research approach has been used in the study to identify the challenges that hindered female progression. The qualitative (exploratory) approach assisted research participants to articulate their experience of the complexity issues that related to female progression (Creswell, 2011:17).

The methodology that underpinned the research was a qualitative research approach with a qualitative research design. The qualitative research used was to fully discover, explore and gain a nuanced understanding of female progression (Creswell, 2013: 55 and Saunders, Lewis and Thornhill, 2012: 15). Thus, a qualitative approach was selected to gain a nuanced understanding of female progression in formal employment and entrepreneurship (Neuman, 2011: 65).

Bracketing on the other hand is a qualitative research method aimed at alleviating the detrimental effects of preconceptions and assumption that might flaw the research completed (Newman, 2012:1).

For this study the population composed of females with an industry relevant degree and between five and ten years working experience. LinkedIn was used as a database to identify the research participants. Females were chosen based on their work experiences in the executive space of companies (top notch positions) and their development of pursuing a career in entrepreneurship. The predetermined criteria were met by all my fellow participants, namely: gender, duration of service in the organization; duration of service in their entrepreneurial venture, age, highest educational qualification and their professional level. For the said study in terms of data collection instruments unstructured interviews were conducted using an interview guide.

In addition, Saunders, Lewis and Thornhill (2012: 75) the raw data on female progression was condensed into categories or themes based on valid inference and interpretation. This process used inductive reasoning, by which themes and categories emerged from the data through careful examination and constant comparison.

The six steps of thematic analysis will be illustrated here below (Creswell, 2009:185-186):

- Step 1: Transcribing interviews: Organising and preparing data for data analysis. Depending on source of information data needed to be sorted and arranged into various types of information.

- Step 2: When reading data you should develop an overall and general sense and understanding of it.

- Step 3: A coding process is a method of coordinating and organizing the intended material into various segments of texts prior to bringing forth meaning to the information. 
Sooraya Ebrahim \& Shamila Singh "An Understanding into the Dynamics Faced by Females as they Transition from the Corporate Sector into the Abyss of Entrepreneurship"

- Step 4: By identifying and generating a few themes (approximately 7) through the coding process it will help create headings, variables, major findings and a description of people setting and category themes base on the report outcomes.

- Step 5: A narrative passage or paragraph should be used to convey and articulate the analysis findings and a decision needs to be taken on the representation thereof. Thus including a debate on differing themes.

- Step 6: Finally, data analysis for qualitative research refers to the interpretation of the meaning of the data which may take numerous forms. This analysis provided flexibility through conveying personal research- based action meanings as well as adapting to various types of design.

\section{RESULTS AND DISCUSSIONS}

\section{Research Findings}

- The primary research revealed that the challenges experienced by females in progressing in the corporate sector are mostly similar but also there are issues that specific to operating as an entrepreneur. Interesting concepts and issues emerged from the primary research initiated that relates to female progression, advancement and limitations experienced in starting up businesses.

- Female reported that although male domination still prevails, it is the female acquaintance that seems to be pulling down each other (known as 'Queen Bee Syndrome) that adversely affects female progression.

- The findings reveal female sometimes lack the necessary experience and skill required to advance in their careers. In some context females are given equal opportunity but do not have the requisite skills whereas conversely in other context females possess the requisite skills but the opportunities are either limited or not accessible.

- Another interesting finding is that most participants recognise that progression also relates to a persistence, confidence, intrinsic motivation and self-efficacy. In some context the pervasive stereotypes that female are less able, skilled, knowledgeable and reliable hindered progression.

- Another major contributing factor is the wage differentials where males earn more than females doing similar work results in demotivation and low self-esteem.

- The culture of male dominance is pervasive and systemic which marginalises the female voice and interest. The findings found that male dominance is depicted by the exclusive "boy clubs", exclusionary practices and disrespect. In addition, many of the participants conceded that female discrimination was both internally and externally characteristic of the work. The participants agreed that clientslcustomers of the company prefer to receive support and advise from males instead of females. Most of the participants made reference to the "internal thought processes" (self-critique) that hinders female progression.

- On the other side of the coin males are still chosen over their female counterparts as they seem to be more confident, are risk takers and are less empathetic and emotional as opposed to the female gender. The male gender seems to be more resilient and is more free to manoeuvre when required to travel, work late hours in terms of security and experience more freedom in terms of work life balance.

- Another disturbing factor noted is that cultures, traditions, norms, social barriers, race, ethnicity and society as a whole have constrained the female as they opine that belong at home and is the nurturer of the family Thus adding stress and pressures of acceptance from the community while dealing with the added pressures of the world by juggling the household affairs with their career pursuits.

- Furthermore, as people evolve and changes are adopted and accepted, females are supported but face issues such as work-life balance, high divorce rates, stereotyping, stigmatism, personal barriers and mentorship are still pervasive. It was acknowledged by most of the participants that is only the female who have the capacity to break down the barriers encountered and persistence in pursuit of objectives are possible. Furthermore, they indicated that an individual is sometimes the 
Sooraya Ebrahim \& Shamila Singh "An Understanding into the Dynamics Faced by Females as they Transition from the Corporate Sector into the Abyss of Entrepreneurship"

cause of its own destruction through self-imposed limitations. Another common feature that arose was that individuals need to find themselves first and know what their purpose and vision is in order to progress advance successfully.

- Female entrepreneur's participants indicated that access to financial funding was not an issue due their spouses assisting them or saved funds, etc. However, they affirmed that it is still a tough terrain and acceptance of females as entrepreneurs is still taboo and females have to work twice as hard to prove their capabilities.

- The findings also allude that there many successful female role models to mentor, coach and support the professional executive female employee as well as the new age female entrepreneur. The findings conclude that mentoring, coaching and supporting interventions are not structured and formalised. Networking is perceived to be easier for males as they have their sorority and social clubs that they are affiliated to whereas the female gender struggles with this variable due to perceived as the weaker sex.

\section{Recommendations for to Contribute to Female Progression}

Self-development through education, acute self-awareness, belief and confidence in self as well as a sense of continuous learning (soft skills, hard skills, fitness, hobbies and other interests).

- Empowerment, coaching and mentoring programmes need to be developed to enhance the capabilities of the female gender.

- Human Resource policies need to be reviewed and reframed in terms of equality for pay, equal opportunities in all aspects in the work place, especially at the core executive space.

- Work policies need to be revisited in terms of employee wellness and flexibility in the workplace as people strive to balance their household responsibilities with their work or business. Companies need to become for family oriented by providing facilities such as child caring facilities which eliminates the stresses of their mother employees, thus increasing their productivity and loyalty to the companies.

- Government needs provide easier access to funding support and provide training and development to improve and strengthen their business skills. The current empowerment programmes should be monitored and evaluated to assess the impact of the programmes.

- A sisterhood of professionals need to start emerging by celebrating that female sisters' achievements and create networking support groups to facilitate and enhance their power in advancement.

- Share best practices in female progression with aspiring female leaders.

- Female leadership should understand their internal dialogue, stereotypes, self-fulfilling prophecies and beliefs that create limitations and barriers for female progression

- Role model system should be developed, reviewed and evaluated.

- Human resources to do an audit of the levels of inequality that females experience and design aligned intervention strategies.

- An understanding and analysis of the elements that contribute to "Female pull-me down syndrome" and how to overcome these obstacles that hinder female progression

- Further investigation of the intersectionality theory in combating the challenges of female entrepreneurship

- Further investigation of Acker's theory in restructuring of bureaucratic hierarchies in organisation through inclusion of the female gender employment at all structural levels as well as maintaining equality on salary structures for all genders alike

\section{CONCLUSION}

This study highlighted the overall findings and conclusions with regards to the challenges women encounter in progressing in the corporate and entrepreneurship face. The overall conclusions of the primary findings were drawn from the data collected from the women who participated whilst overall 
Sooraya Ebrahim \& Shamila Singh "An Understanding into the Dynamics Faced by Females as they Transition from the Corporate Sector into the Abyss of Entrepreneurship"

conclusions from the literature review were drawn from the literature review. This study will play a significant role in eliminating the challenges faced by women in leadership. The contribution of this study may lead to organisations achieving equity of women and men in the work environment. However, it will take great effort from organizations and women alike. The recognition of the potential barriers caused by gender discrimination will allow women to control some of these barriers such as lack of education, training, and experiences.

\section{ACKNOWLEDGEMENT}

To all the beautiful souls who have accompanied me on this fascinating, awe inspiring journey, my heartfelt gratitude goes out to one all. As the saying goes, 'A journey of a thousand miles begins with just a single step.' A successful master piece that comes to fruition requires a solid foundation and a strong support structure-MY FAMILY and MANCOSA. My fellow participants thank you for your valued contribution to this study. Thank you to my guardian angels, who have guided me, prayed for me and still protect me: Zahid, James, Fatima, late Rookshana and my dissertation supervisor Shamila-you are a pillar and a blessing from God, a priceless gem. Ma (late-grandmother), my soul mate indeed. Thank you God!

\section{REFERENCES}

[1] Acker, J. (2006a).Class Questions: Feminist Answers. Lanham: Rowman \& Littlefield.

[2] Acker, J. (2006b). Inequality Regimes: Gender, Class, and Race in Organizations Gender \& Society. Vol. 20(4).pp 441-464.

[3] Acker, J. (2009). From Glass Ceiling to Inequality Regimes Sociologie Du Travail 51 (2).pp. 199-217.

[4] Adib, A., \& Guerrier, Y. (2003). The Interlocking of Gender with Nationality, Race

[5] Ethnicity and Class: the Narratives of Women in Hotel Work. Gender, Work and Organization. Vol.10 (4). Pp 413-432.

[6] Agbenyegah, A.T (2013). Challenges facing rural entrepreneurship in selected areas in South Africa. Unpublished dissertation report. Potchefstroom Campus of the North-West University.

[7] Ahmad, Z.S. \& Xavier, S.R. (2012). Entrepreneurial environments and growth: Evidence from Malaysia GEM data. Journal of Chinese Entrepreneurship. Vol. 4(1).pp 50-69.

[8] Alvesson, M., and Billing, Y.D. (1997).Understanding Gender and Organizations, Sage. London.

[9] Alvesson, M., \& Billing, Y. D. (2009). Understanding gender and organizations. $2^{\text {nd }}$ Edition. London. England. SAGE.

[10] Anderson, Margaret. (2008) "Thinking about Women Some More: A New Century's View" with Construction of Knowledge.” Pp. 34-52. John Stanfield and Routledge Dennis (eds.) Research in Race \& Ethnic Relations. Newbury Park. CA.Sage Publications.

[11] Antal, B.A. \& Izraeli, D.N. (1993). A global comparison of women in management: Women managers in their homelands and as expatriates. E. Fagenson (Ed.),

[12] Women in management: Trends, issues, and challenges in managerial diversity. Newbury Park, CA.Sage.

[13] Ardagna, S. \& Lusardi, A. (2009)._Heterogeneity in the effect of regulation on entrepreneurship and entry size NBER WP 15510.NBER.Cambridge.

[14] Armstrong, D, Nelms, J, Riemenschneider I, C, \& Reid M. (2012). Revisiting the barriers facing women in Information Systems. Journal of Computer Information Systems.Vol.53 (2). pp. 65-74.

[15] Atkinson, M. A. (1972). "Precise phenomenology for the general scholar", Journal of General Education, 23, 4, pp.261-97. 
Sooraya Ebrahim \& Shamila Singh "An Understanding into the Dynamics Faced by Females as they Transition from the Corporate Sector into the Abyss of Entrepreneurship"

[16] Aurora Chen, Noeleen Doherty \& Susan Vinnicombe. (2012)."Developing women's career competencies through an EMBA": Gender in Management. An International Journal. Vol. 27. (4).pp $232-248$.

[17] AZAPO. (2008). Public hearing: National youth development agency bill. http://www.pmg.org.za/report/20081117-national-youth-development-agency-bill [Accessed on 22 November 2011].

[18] Babita Mathur-Helm. (2005). "Equal opportunity and affirmative action for South African women: a benefit or barrier?” Women in Management Review. Vol.20 (1).pp 56-71.

[19] Bannigan, K., \& Watson, R. (2009). Reliability and validity in a nutshell. Journal of Clinical Nursing.Vol.18 (23).pp 3237-3243. Available from http://web.ebscohost.co [Accessed on 2 September 2014]

[20] Behning, U. and Pascual, A. S. (2000)._"Rethinking the gender contract? Gender mainstreaming in the European employment strategy". ETUI Yearbook. 2000. ETUI. Brussels.

[21] Bell, E.L., and Nkomo, S.M. (2001). Our separate ways: Black and white women and the struggle for professional identity .Boston: Harvard Business School Press.

[22] Bell, L. (2005)_Women-Led Firms and the Gender Wage Gap in Top Executive Jobs.IZA Discussion Paper no. 1689.

[23] Bennett, J. (2002). "How woman can make up for lost time”. Sunday Times.19 May. pp. 12.

[24] Bertrand, Marianne, Claudia Goldin, and Lawrence Katz. (2010). "Dynamics of the Gender Gap for Young Professionals in the Financial and Corporate Sector." American Economic Journal: Applied Economics2. (July): 228.Available from: http://csap.yale.edu/sites/default/ files/files/silbermann.pdf

[25] Bjerk, D. (2008) Glass Ceilings or Sticky Floors? Statistical Discrimination in a Dynamic Model of Hiring and Promotion. Economic Journal, Vol.118 (530).pp961-982.Available from: http://ssrn.com/abstract=1147263

[26] Blau, F.D. and Devaro, J. (2007).New Evidence on Gender Differences in Promotion Rates: An Empirical Analysis of a sample of new hires. Retrieved from Cornell University. School of Industrial and Labour Relations. Available from: http://digitalcommisions.ilr.cornell.edu/ articles/113/

[27] Boardroom-Official journal of chartered secretaries Southern Africa.(2014).Issue 3.SA still has some way to go in building the pipeline of future female leaders. pp 24-25. A PWC Survey. Carmen Le Grange, PWC partner in advisory services.

[28] Booth, A., M. Francesconi, and J. Frank (2003).A sticky floor model of promotion, pay, and gender. European Economic Review.Vol.47.pp 295-322.

[29] Booth, Allison L.and Nolen, P. (2009).Choosing to Compete: How Different are girls and boys? CEPR Discussion Paper 7214.

[30] Booysen,L.A.E. \& Nkomo,S.M. (n.d) Gender Role Stereotyping and Requisite Management Characteristics: The Case of South Africa. Faculty of Economic and Management Sciences.

[31] Booysen, L. (1999). "A review of challenges facing black and white women managers in South Africa". [Online] Available from: www.sabusinessreview.co.za/December1999/ articles/booysen.htm [Accessed on 1 August 2014]

[32] Booysen, L. (2007). Barriers to Employment Equity Implementation and Retention of Blacks in Management in South Africa. South African. Journal of Labour Relations.Vol.31 (1).pp47-71.

[33] Booysen,L.A.E and Nkomo,S.M. (2010) Gender role stereotypes and requisite management Characteristics: Gender in Management. An International Journal. Vol. 25. (4).pp 285 - 300. [Online] Available from: http://dx.doi.org/10.1108/17542411011048164 [Accessed on: 13 November 2014] 
Sooraya Ebrahim \& Shamila Singh "An Understanding into the Dynamics Faced by Females as they Transition from the Corporate Sector into the Abyss of Entrepreneurship"

[34] Booysen, L. and Nkomo, S. (2010). Employment Equity and Diversity Management in South Africa. International Handbook on Diversity Management at Work: Country Perspectives. Cheltenham. Edward Elgar Publishing.

[35] Booysen S. (2013). Twenty years of South African democracy. pp 1-68.[Online] http://www.google.co.za/url?url=http://www.freedomhouse.org/sites/default/files/Twenty\%252 0Years\%2520of\%2520South\%2520African\%2520Democracy\%2520-\%252012\%2520$\% 252017 \% 2520 \% 252013 . p d f \& r c t=j \& f r m=1 \& q=\&$ esrc $=s \& s a=U \& e i=I 7$ wGVNeTFaPmywPCu oKACg\&ved=0CBwQFjAC\&usg=AFQjCNGK1xEjVXaj6Aza_oNQUadDsjXeOA, [Accessed on 25 August 2014].

[36] Budworth, M.H. \& Mann, S.R. (2010). "Becoming a leader: the challenge of modesty for women", Journal of Management Development. Vol. 29. (2). Pp 177 - 186.

[37] Business environment specialists sbp alert (2013) Understanding women entrepreneurs in South Africa. Issue paper3.p1-10. [Online] Available from www.sbp.org.za [Accessed on 20 January 2015]

[38] Business Brief-Business Information you can use. Board Challenges. August/September 2014 Vol.19. (4).Parmi Natesan. Senior governance Specialist. Institute of Directors in Southern Africa (IODSA).parmi@iodsa.co.za

[39] Business Brief-Business Information you can use. Mentorship helps women. October/November 2014 Vol.19. (5).Annie McWalter.CEO. The Hope Factory anniemc@thehopefactory.co.za

[40] Carlson, N. (2013). Sheryl Sandberg Presents: Deeply Troubling Stats about Women. [Online] http://www.businessinsider.com/sheryl-sandberg-presents-mind-blowing-stats-about-how-andwhy-women-hold-themselves-back-2013-2?op=1 [Accessed on 1 August 2014].

[41] Catalyst (2004). "South African women in corporate leadership". Census 2004.Catalyst.New York. NY.

[42] Charles, Maria and David B. Grusky. (2004). Occupational Ghettos: the Worldwide Segregation of Women and Men. Stanford, CA: Stanford University Press.

[43] Chernesky, R. H. (2003)._"Examining the glass ceiling”, Administration in Social Work._Vol. 27. (2).

[44] Cherry, R. (2001). Who gets the good jobs? Rutgers University Press. New Brunswick.

[45] Chowdhury, M.S. (2007). Overcoming entrepreneurship development constraints: the case of Bangladesh. Journal of Enterprising Communities. People and Places in the Global economy. Vol. 1(3). Pp 240-251.

[46] Clarke, M. (2011). "Advancing women's careers through leadership development programs": Employee Relations"'.Vol. 33. (5). Pp 498 - 515.

[47] Cockburn, C. (1991). In the Way of Women: Men's Resistance to sex Equalization in Organisations. London. Macmillan.

[48] Cohen.D. \&Crabtree, B. (2006)_"Qualitative Research Guidelines Project." [Online] Available from: http://www.qualres.org/HomeSemi-3629.html [Accessed on 25 February 2015]

[49] Collins, P. H. (1990). Black Feminist Thought: Knowledge Consciousness and the Politics of Empowerment. Boston. Unwin Hyman.

[50] Collins, P. H. (2000). It's All in the Family: Intersections of Gender, Race, and Nation. U. Narayan, \& S. Harding (Eds.). Decentering the Center: Philosophy for a Multicultural, Postcolonial, and Feminist World. Pp 156-176. Bloomington. Indiana University Press.

[51] Connelly,L.M.(2009). Survey Methods. MEDSURG Nursing. Vol.18. (2). Pp 114-133. [Online] Available from: http://web.ebscohost.com [Accessed on 05 April 2015]

[52] Coulter, M. (2003). Entrepreneurship in action. $2^{\text {nd }}$ edition. Upper Saddle River. New Jersey. Prentice-Hall. 
Sooraya Ebrahim \& Shamila Singh "An Understanding into the Dynamics Faced by Females as they Transition from the Corporate Sector into the Abyss of Entrepreneurship"

[53] Crampton, S. M. and Mishra, J. M. (1999). "Women in management", Public Personnel Management. Vol. 28. (1).pp 87-106.

[54] Creswell, J. W. (2007). Qualitative inquiry and research design: Choosing among five approaches. $2^{\text {nd }}$ Edition. Thousand Oaks. California. Sage

[55] Creswell, J. W. (2008). Educational research: Planning, conducting, and evaluating quantitative and qualitative research .3rd Edition. Upper Saddle River. New Jersey. Pearson Education.

[56] Creswell, J. W. (2009). Research Design: Qualitative, Quantitative, and Mixed Methods Approaches. $3^{\text {rd }}$ Edition. Los Angeles: Sage Publications. Inc.2009.

[57] Creswell, J.W (2013). Qualitative Inquiry: Qualitative Inquiry and research design. $3^{\text {rd }}$ Edition. Los Angeles, California: Sage publications.

[58] Creswell, J.W. (2013). Research Design: Qualitative, Quantitative and Mixed Methods Approaches. $4^{\text {th }}$ Edition. Thousand Oaks. California. Sage

[59] Crotty, M. (1996). Phenomenology and nursing research. Melbourne: Churchill Livingston.

[60] Cullen, J. \& Gordon, R. (2009). Taxes and entrepreneurial risk-taking: Theory and evidence in the US. Journal of Public Economics. Vol. 91. Pp 479-1505.

[61] Dana M. Britton. \& Laura Logan. (2008).Sociology Compass._Vol. 2. (1). Pp 107-121. [Online] Available from: http://DOI: 10.1111/j.1751-9020.2007.00071.x [Accessed on 10 March 2015]

[62] Datta Gupta, Nabanita. Nina Smith, and Mette Verner. (2008). "The Impact of Nordic countries' family friendly policies on employment, wages, and children." Review of Economics of the Household, Vol. 6. (1). Pp 65-89.

[63] Davidson, M. J. and Burke, R. J. (2004). "Women in management worldwide: facts, figures, and analysis- an overview". Davidson, L. and Burke, R. (Eds). Women in Management Worldwide: Progress and Prospects. Ashgate. London.

[64] Davidson T.L. (2014). Phenomenological Research Using a Staged Multi-Design Methodology. International Journal of Business Humanities and Technology. Vol. 4. (2).March 2014. Pp 1-9

[65] Davis, K. (2008). Intersectionality as Buzzword: A Sociology of Science Perspective On What Makes a Feminist Theory Successful: Feminist Theory. Vol.9.pp 67-83.

[66] O’Neil, D.A., Hopkins, M.M. \& Sullivan, S.E. (2011). "Do women's networks help advance women's careers?" Career Development International. Vol. 16, (7).pp 733 - 754.

[67] Denzin, N. K., \& Lincoln, Y. S. (2005).EDS. Handbook of Qualitative research. $3^{\text {rd }}$ Edition. Thousand Oaks. California. Sage

[68] Denzin, N. K., \& Lincoln, Y. S. (2011). The Sage handbook of qualitative research. $4^{\text {th }}$ Edition. Thousand Oak. California.

[69] Develi, S., E.I., Sahin, E.B. \& Sevimli, U. (2011). Entrepreneurship and importance of personality on entrepreneurship: A research on trainees of entrepreneurship education program. International Journal of Business Management Studies. Vol.3. (1). Pp 115-124.

[70] Dhamoon, R. K. (Performer). (2010).Spring. Lecture on Colonialism, Post-Colonialism, and Anti-Racism. The University of the Fraser Valley. Abbotsford. British Colombia. Canada.

[71] Dhamoon, R. K. (2011). Considerations on Mainstreaming Intersectionality. Political Research. Quarterly, Vol.64. (1). Pp 230-243.

[72] Durheim, K. (2006). Research Design. M.Terre Blanch, K. Durrheim and D.Painter (Eds).Research in Practice. Applied Methods for the social sciences. Cape Town. UCT.

[73] Eagly, A.h. \& Schmidt, M.C.H. (2001) The Leadership Styles of Women and Men. Department of Psychology. North western University. 
Sooraya Ebrahim \& Shamila Singh "An Understanding into the Dynamics Faced by Females as they Transition from the Corporate Sector into the Abyss of Entrepreneurship"

[74] Elmuti, D., Jia, H., Davis, H. (2009). "Challenges Women Face in Leadership Positions and Organisational Effectiveness: An Investigation”. Journal of Leadership Education.Vol. 8, (2). Pp 167-186.

[75] Erwee, R. (1994). "South African women: changing career patterns". Adler, N. J. and Izraeli, D. N. (Eds).Competitive Frontiers. Blackwell. Cambridge.MA. pp 325-42.

[76] Executive directors' remuneration: practices and trends report 2014-PWC. $6^{\text {th }}$ Edition .July 2014.pp 35-50 [Online] Available from: http://www.pwc.co.za/en_ZA/za/assets/pdf/executivedirectors-remuneration-report-july-2014.pdf. [Accessed 07 march 2015]

[77] Ezzedeen, S.R. \& Ritchey, K, G. (2009). "Career advancement and family balance strategies of executive women": Gender in Management. An International Journal. Vol. 24. (6).pp. 388 411.

[78] Factor-Inwentash Faculty of Social Work. University of Toronto.246 Bloor Street West, Toronto, Canada, M5S 1V4. [Email: lea.tufford@utoronto.ca]

[79] Ferdman, B. (2000). Paradoxes of Intersectionality: Theorizing Inequality in the Dutch Police through Structure and Agency [Online] Available from http://10.1177/1350508409350042. Vol.17. (1). Pp 53-75. [Accessed on 25 May 2015]

[80] Ferguson, Kathy E. (1984).The Feminist Case against Bureaucracy. Philadelphia. Temple. University Press.

[81] Fielden, Sandra \&Davidson, M._International Research Handbook on Successful Women Entrepreneurs. London. Edward Elgar.2010.

[82] Fonseca, R., Michand, P. \& Sopraseuth, T. (2007). Entrepreneurship, wealth, liquidity constructs and start-up costs. DP 2874. Bonn. Institute for the study of labour.

[83] Foss, Nicolai J. and Peter G. Klein._Organizing Entrepreneurial Judgment: A New Approach to the Firm.

[84] Fryer, R.G. (2007). Belief Flipping in a Dynamic Model of Statistical Discrimination. NBER Working Paper no.12174. [Online] Available from: www.nber.org/papers/w12174.pdf. [Accessed on 15 February 2015]

[85] Gibbs S. (2014). "Women in technology: no progress on inequality for 10 years" [Online] Available from: http://www.theguardian.com/technology/2014/may/14/women-technologyinequality-10-years-female (Accessed on 1 July 2015).

[86] Giorgi, A. (1992). Description versus Interpretation: Competing Alternative Strategies for Qualitative Research. Journal of Phenomenological Psychology.Vol.23. (2). Pp 119-135.

[87] Giorgi, A. (2008). Phenomenology. In J.A. Smith (Ed).Qualitative Psychology: A Practical Guide to Research Methods. Pp 27-52. London. Sage.

[88] Glaeser, E.L., Rosenthal, S.S., \& Strange, W.C. (2010). Urban economics and entrepreneurship. Journal of Urban Economics.Vol. 67. (1). Pp 1-14.

[89] GTBR. (2012). Women in senior management: still not enough. Pp 3-12. () 2012 Grant Thornton International Ltd. All rights reserved.

[90] Gupta, V.K., Turban, D.B., Wasti, S.A., \&Sikdar, A. (2005). Entrepreneurship and Stereotypes: Are Entrepreneurs from Mars or from Venus? Academy of Management Best Conference Paper.

[91] Gupta, V.K., Turban., D.B., Wasti, S.A., \&Sikdar, A. (2009). The Role of Gender Stereotyping in Perceptions of Entrepreneurs and Intentions to become an Entrepreneur. Baylor University.

[92] Hancock, A.-M. (2007). When Multiplication Doesn't Equal Quick Addition: Examining Intersectionality as Research Paradigm. Perspectives on Politics .Vol. 5 (1). Pp 63-79.

[93] Hansen, K. (2008). The Value of a Mentor. QuintCareers.com. [Online] Available from: http://www.quintcareers.com/mentor_value.html [Accessed on 1 June 2015]. 
Sooraya Ebrahim \& Shamila Singh "An Understanding into the Dynamics Faced by Females as they Transition from the Corporate Sector into the Abyss of Entrepreneurship"

[94] Hatch, M.J. \& Cunliffe, A.L. (2006). Organization theory. Modern, symbolic, and postmodern perspectives. 2nd Edition. Oxford University Press.

[95] Hayfaa Tlaiss Saleema Kauser, (2010). "Perceived organizational barriers to women's career advancement in Lebanon": Gender in Management. An International Journal. Vol. 25. (6).pp $462-496$.

[96] Hayfaa Tlaiss Saleema Kauser, (2011). "The impact of gender, family, and work on the career advancement of Lebanese women managers", Gender in Management: An International Journal. Vol. 26 (1).pp $8-36$.

[97] Heilman, M.E., Wallen, A.S., Fuschs, D. \& Tamkins, M.M. (2004).Penalties for Success: Reactions to Women who Succeed at Male Gendered Typed Tasks. Journal of Applied Pscychology. Vol 89(3).pp416-427.

[98] Henkeman, S. (2011a, April). Lecture. (A. Warnat, Interviewer) Henkeman, S. (2011b, February). Multi-Perspective Analysis Lecturer. (A. Warnat, Interviewer) Cape Town, Western Cape, South Africa.

[99] Herrington, M. \& Wood, E. (2003). Global entrepreneurship monitor: South African Executive Report. Cape Town: University of Cape Town. Graduate School of Business Management.

[100] Hill Collins, P. (1998) it's all in the family Intersections of Gender, Race and Nation.Vol13 (3). Border Crossings: Multicultural and Post Coloniol Feminist Challenges to Philosophy. (Part2) (summer, 1998).pp62-68.

[101] Hills, G. E. \& Shrader, R. C. (1998). Successful entrepreneurs' insights into opportunity recognition. [Online] Available from: URL:http://ww.babson.edu/entrep/fer/papers98/I/I_A/I_ A_text.htm.Ireland.[Accessed on 15 June 2015]

[102] Hochschild, A. (1983). The managed heart: Commercialization of human feeling. Berkeley: University of California Press.

[103] Holsti, O.R (1968). Content Analysis. G. Lindzey \& E. Aaronson (Eds). The Handbook of Social Psychology Reading, MA: Addison-Wesley. Journal of General Education.1972.Vol 23. Pp 261-297.

[104] Holvino, E. (2008).Intersections: The Simultaneous of Race, Gender, and Class in Organisation Studies. Gender and Work and organization.Vol17 (3).pp248-277. [Online] Available from: http://doi.10.1111/j.1468-0432,2008,0040.26 [Accessed on 4 April 2015]

[105] Hooks, b. (2001). Salvation: Black People and Love. New York. Harper Collins Publishers.

[106] Hooks, b. (2000). Visionary Feminism.B. Hooks. Feminsim is for everybody: Passionate Politics. Pp 110-118. London. Pluto Press.

[107] Itzen, C \& Newman, J. (2005).Gender, Culture and Organisational Change: Putting Theory into Practice. Taylor and Francis Group. United Kingdom.

[108] James T., Smith R., Roodt J., Primo N. \& Evans N., (2006). Women in the Information and Communication Technology Sector in South Africa. Funded by the Embassy of Finland. South Africa.

[109] James, T., Esselaar, P., and Miller, J. (n.d.). Towards A Better Understanding of the ICT Sector in South Africa: Problems and Opportunities for Strengthening the Existing Knowledge Base. [Online] Available from:_http://www.tips.org.za/files/498.pdf [Accessed 22 January 2015]

[110] Janssens, M. and Zanoni, P. (2005) "“Many Diversities for Many Services": Theorizing Diversity (Management) in Service Companies': Human Relations. Vol. 58. (3). Pp 311-40.

[111] Jorgens, C. (2006). Perceptions of Employment Equity Implementation at a Major South African Multi-National Financial Corporations. Postamble .Vol.2. (1). Pp 30-45.

[112] Kanter, Rosabeth Moss. (1977).Men and Women of the Corporation. New York: Basic Books. 
Sooraya Ebrahim \& Shamila Singh "An Understanding into the Dynamics Faced by Females as they Transition from the Corporate Sector into the Abyss of Entrepreneurship"

[113] Kelly, C.W. 2007. Aligning the Diversity "Rubik" Cube: Conceptualising transformative practice. South African Journal of Labour Relations. Vol. 31. (2). Pp 10-31.

[114] Kerfoot, D., and David. Journal of Management Studies.1993).(2007)._Pp 659-677. [Online] Available from:.http://DOI: 10.1111/j.1467-6486.1993.tb00320.x [Accessed on 12 May 2015].

[115] Kiaye, R, E. \& Anesh, M, S. (2013). "The glass ceiling: a perspective of women working in Durban", Gender in Management. An International Journal.Vol. 28. (1).pp 28 - 42.

[116] King, N. \& Horrocks, C. (2010). Interviews in qualitative research. London. Sage Publications.

[117] Klippendorff K. (2003). An Introduction to content analysis. Vol11. Pp 239-265. [Online] Available from: http://www.google.co.za/url?url=http://depts.washington.edu/uwmenair/ chapter11.content.analysis.pdf\&rct=j\&frm $=1 \& q=\&$ esrc $=\mathrm{s} \& \mathrm{sa}=\mathrm{U} \& \mathrm{ei}=\mathrm{Q} 7 \mathrm{gGVIKvEdfjapa8gqg}$ G\&ved=0CBgQFjAB\&usg=AFQjCNFvML-q2PpkF33N4kGJWE-43fTTpw_ [Accessed on 25 May 2015].

[118] Kobia M. (2012). "Effects of social cultural beliefs on women Career Progression in Kenya's Civil Service”. International Journal of Advances in Management and Economics. Vol 1. (6). Pp 214-219.

[119] Kothari, C.R. (2004). Research Methodology: Methods and Techniques. $2^{\text {nd }}$ Edition. New Age International. New. Delhi.

[120] Kumar, R. (2011). $3^{\text {rd }}$ Edition. London. Sage Publications Ltd.

[121] La Pierre, T.K. \& Zimmerman, M.K. (2012). "Career advancement and gender equity in healthcare management ", Gender in Management. An International Journal. Vol. 27. (2). Pp $100-118$.

[122] Leedy, P.D. \& Ormrod, J.E. (2005). Practical research: planning and design. $8^{\text {th }}$ Edition. New Jersey: Pearson Merrill Prentice Hall.

[123] Lisa M. Given (Ed.) (2008). The Sage Encyclopaedia of Qualitative Research Methods. Sage: Thousand Oaks.California.Vol.2. pp 697-698.

[124] Littrell, R.F. and Nkomo, S.M. (2005). "Gender and race differences in leader behaviour preferences in South Africa," Women in Management Review. Vol. 20. (8). Pp 562-580.

[125] Lorra M. Brown, (2010). "The relationship between motherhood and professional advancement": Employee Relations. Vol. 32. (5). Pp 470 - 494.

[126] Marshall, C \& Rossman, G.B. (2010). Designing qualitative research $.5^{\text {th }}$ Edition. Thousand Oaks. London. Sage Publications.

[127] Matshediso M. (2014). South Africa: SA Women Have Pioneered Economic Freedom. [Online] Available from: http://allafrica.com/stories/201408240097.html [Accessed on 1 April 2015].

[128] Mathur-Helm, B. (2002). "Expatriate women managers: at the crossroads of success, challenges and career goals": Women in Management Review. Vol.17. (1).

[129] Mathur-Helm, B. (2004). "Women in management in South Africa". Davidson, L. and Burke, R. (Eds).Women in Management Worldwide: Progress and Prospects. Ashgate. London.

[130] Maume, D. J. Jr (2004). "Is the glass ceiling a unique form of inequality? Evidence from a random effects model of managerial attainment": Work and Occupations. Vol. 31. (250).

[131] McCall, Leslie. (2005). “The Complexity of Intersectionality” Signs. Journal of Women in Culture and Society .Vol.30. (3).pp1771-1800.

[132] McIntosh, P. (1986). White Privileged and Male Privileged: A Personal Account of Coming to See Correspondences through Work in Women's Studies. Massachusetts Center for Research on Women. Massachusetts. Anna Wilder Phelps Fund.

[133] Meyerson, D. E. and Fletcher, J. K. (2000). "A modest manifesto for shattering the glass ceiling”. Harvard Business Review. January/February. pp 127-136. 
Sooraya Ebrahim \& Shamila Singh "An Understanding into the Dynamics Faced by Females as they Transition from the Corporate Sector into the Abyss of Entrepreneurship"

[134] Miliszewska I., Moore, A. (2010). "Encouraging Girls to consider a Career in ICT: A Review of Strategies”. Journal of Information Technology Education. Innovation in Practice. Vol. 9. Pp144- 163.

[135] Morrison, A., White, R. P. and Veslor, E. (1987). Breaking the Glass Ceiling: Can Women Reach the Top of Americas largest Corporations?, Persues Publishing, Cambridge, MA.

[136] Moustakas, C. (1994). Phenmenology Research methods. Thousand Oaks, California: Sage Publications.

[137] Mukulu, E. (2012). "Perceived Organisational Barriers to Women Career Progression in Kenyas Civil Service”. International Journal of Advances in Management and Economics. Vol 1. (6) pp 203-213.

[138] Naudé, W. (2011). Entrepreneurship is not a binding constraint on growth and development in the poorest countries: World Development. Vol.39. (1).pp 33-44.

[139] Neuman, W.L (2007).Basics in Social research Methods: Qualitative and Quantitative methods. Pearsons. Allyn and Bacon.

[140] Neuman, W.L. (2006). Social research methods: qualitative and quantitative approaches. $6^{\text {th }}$ Edition. Boston. Pearson Education Inc.

[141] Niederle, M. and Vesterlund, L. (2007). Do women shy away from competition? Do Men compete too much? Q.J. Economic Journal. Vol .122.pp1067-1101. [Online] Available from:http://qje.oxfordjournals.org/content/122/3/1067 [Accessed 20 January 2015]

[142] Newman, P. University of Toronto, Canada published online before print October 21, (2010) http://doi: 10.1177/1473325010368316_Qualitative Social Work January 2012 vol. 11. (1) .pp 80-96. The Qualitative Report (2013).Vol.18. Article 59.pp 1-9 [Online] Available from: http://www.nova.edu/ssss/QR/QR18/chan59.pdf_[Accessed on 01 February 2015]

[143] Nirodha Gayani Fernando Dilanthi Amaratunga Richard Haigh, (2014). "The career advancement of the professional women in the UK construction industry". Journal of Engineering, Design and Technology. Vol. 12. (1). Pp 53 - 70.

[144] Nkomo, S. M. and Ngambi, H. C. (2009) "African women in leadership: Current knowledge and a framework for future studies". International Journal of African Renaissance Studies. Vol. 4. (1). Pp 31-48.

[145] Nombela, M, (2014) Cultures of Inequality: Exploring Gender and race in a South African University. Published PHD Thesis. Cardiff Business School. [Online] Available from www.orca.cf.ac.uk/68770/ [Accessed on 20 February 2015]

[146] Obioman,P.H., Tickles,V.C., Wowo,A.H., \& Holland-Hunt,S.(2007).Advancement of Women of Colour in Science, Technology, Engineering and Maths(STEM) Disciplines. Johnson C.Charlotte. North Carolina.

[147] Oseifuah, E.K. (2010).Financial literacy and youth entrepreneurship in South Africa. African journal of Economic and management studies. Vol.1, (2).Pp 164-182.

[148] O'Neil, R.C and Viljoen, L. (2001) Support for female entrepreneurs in South Africa: Improvement or decline?. Journal of family Ecology and Consumer Sciences. Vol.29.p37. [Online].Available from: www.ajol.info/index.php/jfecs/article/viewfile/52807/41410 [Accessed on 20 December 2014]

[149] Pai.K. \& Vaidya, S. (2009). "Glass Ceiling: Role of Women in Corporate World.” Competitiveness Review. Vol.19. (2).pp 106-13. Academic Search Complete. Web. 7 Mar. 2013.

[150] Phoenix, A. (2006). Editorial: Intersectionality. European Journal of Women's Studies.Vol.13. (3).pp 187-192.

[151] Parahoo, K. (2006). Nursing research: Principles, process and issues. $2^{\text {nd }}$ Edition. 
Sooraya Ebrahim \& Shamila Singh "An Understanding into the Dynamics Faced by Females as they Transition from the Corporate Sector into the Abyss of Entrepreneurship"

[152] Patton, B. M. Q. (2002). Qualitative research and evaluation methods .3 ${ }^{\text {rd }}$ Edition. Thousand Oaks. California. Sage.

[153] Personnel Today (2007). "London Business School study finds flexible working, mentoring and networking groups are not enough to help more women into leadership roles". [Online] Available from: http://www.personneltoday.com/hr/london-business-school-study-findsflexible-working-mentoring-and-networking-groups-are-not-enough-to-help-more-womeninto-leadership-roles/_ [Accessed on 1 September].

[154] Peter, H. (2003). Risk, Rescue and Righteousness: How Women Prevent Themselves from Breaking Through the Glass Ceiling. Hagberg Consulting Group. San Mateo.CA. [Online] Available from: www.hcgnet.com/article/ female-executives [Accessed on 1 August 2014].

[155] Primeau, L. A. (2003). Reflections on self in qualitative research: Stories of family.

[156] Powell, G. N. and Butterfield, D. A. (2002). "Exploring the influence of decision makers' race and gender on actual promotions to top management", Personal Psychology. Vol. 55. (2).

[157] Powell, G. N., Butterfield, D. A., \&Parent, J.D. (2002).Gender and Managerial stereotypes: Have the Times Changed? Journal of Management. Vol.28. (2).pp177-193.

[158] Rasmussen, E. \& Sorheim, R. (2006). Action based entrepreneurship education. Technovation. Vol. 26. (2). Pp 185-194.

[159] Reskin, B. F. and Padavic, I. (2001). Men and Women at Work. $2^{\text {nd }}$ Edition. Pine Forge Press. Thousand Oaks.CA.

[160] Rothenberg, P. (2000). Invisible Privilege. Lawrence. University of Kansas Press.

[161] RSA (2013). South Africa's Economic Transformation: A Strategy for Broad-Based Black Economic Empowerment. [Online] Available from: www.gov.za/documents/download.php?f= 70187 [Accessed on 1 August 2014].

[162] RSA, (2013). Women Empowerment and Gender Equity Bill. pp 2-29.

[163] Ryan M. Haslam A. (2006). "What lies beyond the glass ceiling? The glass cliff and the potential precariousness of women's leadership positions". Vol. 14. (3). Pp 3-5.

[164] SAHO (2014). "History of women's struggle in SA" [Online]. Available from: http://www.sahistory.org.za/article/history-womens-struggle-south-africa. [Accessed on 1 August 2014].

[165] Sanders, P (1982). Phenomenology: A New Way of Viewing Organizational Research. Academy Of Management Review. Vol.7. (3). Pp 353-360. Business Source Premier. EBSCO host.

[166] Sanghani R. (2013). "Glass ceiling is getting thicker for women". [Online] Available From: www.telegraph.co.uk/women/women-business/10327963/glass-ceiling-is-getting-thicker-forwomen-html [Accessed on 1 August 2014]

[167] Saunders, M.N, Lewis P. and Thornhill, A. (2009). Research Methods for Business Students. $5^{\text {th }}$ Edition. England. Pearson Education Ltd.

[168] Schein, V.E. (2001). A global look at psychological barriers to women's progress in management. Journal of_Social Issues. Vol. 57.pp 675-688.

[169] Schmitt-Rodermund, E. (2007). The long way to entrepreneurship: Personality, parenting, early interests, and competencies as precursors for entrepreneurial activity among the 'Termites'. In R. K. Silbereisen, \& R. M. Lerner (Eds.), Approaches to Positive Youth Development. pp 205224. London. Sage.

[170] Schneider, D. J. (2004). The psychology of stereotyping. New York. NY Guilford Press.

[171] Schreier, M. (2012). Qualitative content analysis in practice. Thousand Oaks. CA. Sage. 
Sooraya Ebrahim \& Shamila Singh "An Understanding into the Dynamics Faced by Females as they Transition from the Corporate Sector into the Abyss of Entrepreneurship"

[172] Shajahan, S. (2009) Introduction to Business Research Methods. Jaico Publishing House. Mumbai.

[173] Sharma S., Sharma M. (2012). Gender equality in the workplace: the perceptive reality, Social Sciences Directory Vol. 1. (1).pp 19-33.

[174] Shields, S.A. (2008).An Intersectionality Perspective.Vol59 (2-3).pp301-311. [Online] Available on http://D0110.1007/5-11199-008-9501-8 [Accessed on 20 May 2015]

[175] Singh, V. and Terjesen, S. (2008). "Female presence on corporate boards: a multi-country study of environment context”. Journal of Business Ethics. Vol. 83. (1). pp. 55-63.

[176] Simard, C. Henderson, A.D. (2013). Climbing the Technical Ladder: Obstacles and Solutions for Mid-Level women in Technology. Pp 3-73. [Online]. Available from:. http://anitaborg.org/ wpcontent/uploads/2013/12/Climbing_the_Technical_Ladder.pdf [Accessed on 3 September 2014].

[177] Smith, A. (2006)._Heteropatriarchy and the Three Pillars of White Supremacy. In Intersectionality and Employment Equity in South Africa 103 Color of Violence: The INCITE! Anthology. pp 66-73. Massachusetts. South End Press Cambridge.

[178] Smith, David Woodruff. "Phenomenology", The Stanford Encyclopaedia of Philosophy. Winter 2013 Edition. Edward N. Zalta.ed. [Online]. Available from: http://plato.stanford.edu/archives/ win2013/entries/phenomenology/>

[179] Smith, P., Peter Caputi, P. \&Crittenden, N. (2012). "How are women's glass ceiling beliefs related to career success?" Career Development International. Vol. 17. (5).pp 458 474.ingstoke.Palgrave Macmillan.

[180] Smooth. (2011). 'Standing for Women? Which Women? The Substantive Representation of Women's Interests and the Research Imperative of Intersectionality': Politics and Gender. Vol. 7. (3).pp 436-441.

[181] Strauss, A. \& Corbin, J. (2008). Basics of qualitative research: techniques and procedures for developing grounded theory. $3^{\text {rd }}$ Edition. Los Angeles. Calif. Sage Publications Inc.

[182] Steyn, M., \& van Zyl, M. (2009). The Prize and The Prince: Shaping Sexualities in South Africa. Cape Town: HSRC Press.

[183] Strout, E. (2001). Confronting the glass border. Sales and Marketing Management. Vol.153. (19). Business Review.Vol.81. pp 18-19.

[184] Swim, J., Borgida, E., Maruyama, G., \& Myers, D. G. (1989). Joan McKay versus John McKay: Do gender stereotypes bias evaluations. Psychological Bulletin.Vol.105.pp 409-429.

[185] Symanowitz, C.Finweek Magazine in their 29-Nov-2012 issue. Supporting our women entrepreneurs: How does South Africa stack up?13-Dec-2012 [Online] Available from: http://colettesymanowitz.com [Accessed on 26/02/2015]

[186] Tanwir, M. (2014). Gender Neutrality and the Pakistani Bureaucracy. Journal_of International Women Studies.Vol15 (2).pp143-164. [Online] Available from: http://vc.bridgew.edu/jiws/ vol15/1552/10 [Accessed on 20 March 2015]

[187] Terreblanche, S. (2002). A History of Inequality in South Africa 1652-2002.Scottsville. University of Natal Press.

[188] Venkata Ravi, R., \& Reddy Narayana, V. (2004). "Empowerment of People” Grassroots strategies and issues. 
Sooraya Ebrahim \& Shamila Singh "An Understanding into the Dynamics Faced by Females as they Transition from the Corporate Sector into the Abyss of Entrepreneurship"

[189] Verloo, M. (2006). Multiple Inequalities, Intersectionality and the European Union. European Journal of Women's Studies. Vol.13. pp 211-228.

[190] Warnat, A.E. (2012) Intersectionality and Employment Equity in South Africa 1 Intersectionality and Employment Equity in South Africa. Masters of Philosophy in Justice and Transformation

[191] Faculty of Humanities. Published MBa Dissertation. University of Cape Town. [Online] Available from: www.uctscholar.uct.ac.za:1801/webclient/streamgate?folder_id=08dus=14290 $66231454 n 925$ [Accessed on 20 November 2014]

[192] Waters, K.B., \& Conway, C.B.eds. (2007).Black Women's Intellectual Traditions: Speaking their minds. Lebanon. N/University Press of New England.

[193] Wellington, S., Kropf, M. \& Gerkovich, P. (2003). What's holding women back? Harvard Business Review. [Online] Available from: http://hbr.org/2003/06/whats-holding-womenback/ar/2 (Accessed on 27 August 2014).

[194] Weyer, B (2007),"Twenty years later: explaining the persistence of the glass ceiling for women leaders". Women in Management Review, Vol. 22 (6):482 - 496 [Online] Available from: http://dx.doi.org/10.1108/09649420710778718 [Accessed on 10 December 2014]

[195] Whitmarsh, L, B., Cooper, D., Hawkins-Rodgers, Y. \& Keyser Wentworth, D (2007). Choices and Challenges: A Qualitative Exploration of Professional Women's Career Patterns. Career Development Quarterly. Vol.55 (3). Pp 225-236.Business Source Premier. EBSCOhost. [Accessed 20 August 2014.

[196] Wilson, F., Kickul, J. and Marlino, D. (2007).Gender, entrepreneurial Self-efficacy, and entrepreneurial career Intentions: implications for entrepreneurship education,

[197] Entrepreneurship: Theory and Practice Vol.31. pp 387-406.Drive economic growth. Research Policy. Vol.35. pp 1499-508.

[198] Wings L (2013). "The continued challenges facing women in the modern South African workplace". [Online] Available from: http://m.bizcommunity.com//Article.aspx?l=196\&c= 22\&i=98357 [Accessed on 1 August 2014].

[199] Wood, U.J.G. (2011)._"Women managers' career progression: an Asia Pacific perspective", Gender in Management”’ An International Journal. Vol. 26. (8). Pp 590 - 603.

[200] Writer S. (2013). "Girls encouraged tochoose ICT". [Online] Available from: http://www. itweb.co.za/index.php?option=com_content\&view=article\&id=67067 [Accessed on 1 August 2014].

[201] Yukl, G. (2013).Eighth Edition. Leadership in Organizations. University of Albania. State university of New York. Person. Prentice Hall.

[202] Zanoni, P., M., Janssens, Y. Benschop and S. Nkomo (2010) 'Unpacking diversity, grasping inequality: Rethinking difference through critical perspectives', Organization. 17: 9-29.

[203] Zanoni, P. Diversity in the lean automobile factory: doing class through gender, disability and age organisation. [Online] Available from: http//: doi: 10.1177/1350508410378216_Vol.18. (1).pp 105-127.

[204] Zimmerman, D.H. and West, C. (1975). "Sex roles, interruptions and silences in conversation". In Thorne, B. and Henley,N.(eds) Language and Sex: difference and dominance, Rowely, Mass., Newbury House. 


\section{AUTHORS' BIOGRAPHY}

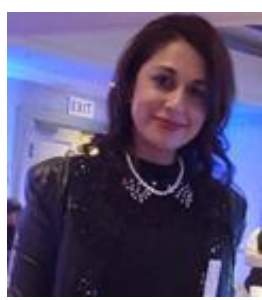

Sooraya Ebrahim, is a dynamic and charismatic, resplendent individual who is an executive managing mentoring consultant and lecturer by profession. Her skills scope has spanned into various industries essentially the Hospitality, Corporateretail, Basic Commodity trading and the Academic arena. She is currently pursuing her writing skills and writing a book, titled 'No Comment: The Questions Unleashed." As her journey of life progressed, she was a survivor of thyroid cancer. Her tenacity, drive and enthusiasm, passion and purpose of life catapulted her to strive further in supporting others wilfully and effectively.

Dr Shamila Singh, has extensive experience as an academic, consultant, coach and Shared Services Manager. She has been appointed as Interim Head of the SABPP HR Audit Unit, the first national HR audit unit of its kind in the world. Shamila completed BBA, and BA (Hons) in Industrial Psychology degree at Unisa as well as MBL and DBL degrees at the Unisa School of Business Leadership. She specialises in HR Management and Corporate Governance and focuses on Strategy, Talent Management, HR Risk Management, Performance Management, Employment Relations Management, Organisation Development and HR Measurement as key standard elements of the National HR Standards developed by SABPP. Shamila is registered as a Master's HR Professional with SABPP. She delivered several papers at local and international conferences. Shamila is involved in academic and research work for Unisa, Mancosa, Open University, and is the Director of Unique Consulting Services. Shamila is doing research supervision for Unisa School of Business Leadership, Mancosa, Regent Business School, Durban University of Technology, University of Kwazulu-Natal and the Institute of Marketing Management. She also chairs the SABPP Monitoring and Evaluation Committee to govern the quality assurance of accredited learning providers as delegated to SABPP by the Quality Council for Trades and Occupations. 